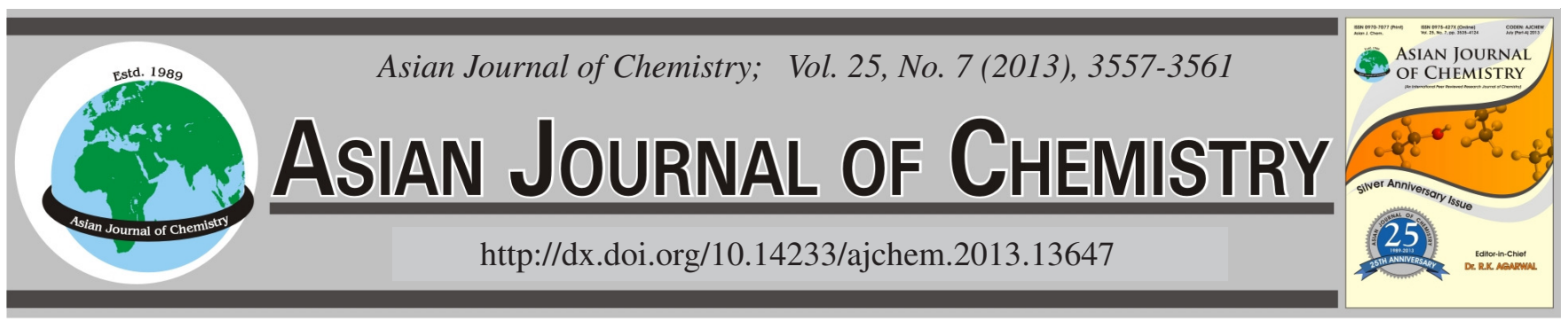

\title{
Removal of Arsenic from Aqueous Environments Using Moringa peregrina Seed Extract as a Natural Coagulant
}

\author{
Edris Bazrafshan ${ }^{1}$, Hamed FAridi $^{1}$, Ferdos Kord Mostafapour ${ }^{1}$ and Amir Hossein Mahvi ${ }^{2,3, *}$
}

${ }^{1}$ Health Promotion Research Center, Zahedan University of Medical Sciences, Zahedan, Iran

${ }^{2}$ School of Public Health and Institute for Environmental Research, Tehran University of Medical Sciences, Tehran, Iran

${ }^{3}$ National Institute of Health Research, Tehran University of Medical Sciences, Tehran, Iran

*Corresponding author: Fax: +98 21 88954914; Tel +98 9123211827; E-mail: ahmahvi@yahoo.com

\begin{abstract}
Arsenic is considered as one of the most hazardous elements for the living organisms and its presence in natural waters, can result in serious environmental problems. In this study, Moringa peregrina seed extract ability in a batch system to remove arsenate from aqueous solutions was investigated. The effects of major operating variables such as coagulant dose $\left(0.1-5 \mathrm{~mL} \mathrm{~L}^{-1}\right)$ and $\mathrm{pH}(2-11)$ were investigated. The optimum $\mathrm{pH}$ for removal of arsenic by coagulation using Moringa peregrina seed extract was 6 and the highest removal was found to be $98.61,99.032$ and $98.976 \%$ at initial arsenic(V) concentration 100, 200 and $500 \mu \mathrm{g} \mathrm{L}^{-1}$ respectively, as a result of precipitation, co-precipitation and adsorption mechanisms. According to achieved results, it was defined that Moringa peregrina seed extract not only was an inexpensive coagulant, but also a quite effective factor in removal of arsenic $(\mathrm{V})$ from aqueous environments.
\end{abstract}

Key Words: Arsenic removal, Moringa peregrina, Coagulation, Natural coagulants.

\section{INTRODUCTION}

Nowadays heavy metals pollution has become one of the most important environmental problems ${ }^{1-4}$. The presence of toxic metals in water sources is an important issue in water and wastewater treatment, as their consequences on human health have been well established ${ }^{5-8}$.

Arsenic (a semi-metallic element) is one of the most toxic, carcinogenic and natural contaminant found in water resources $^{9,10}$. The main source of arsenic as a heavy metal in drinking water is arsenic-rich rocks through which the water has percolated, because arsenic is a naturally occurring element in the earth's crust and is found throughout the environment ${ }^{11}$. Arsenic may also be derived from mining or industrial activity in some areas ${ }^{12}$. In nature arsenic occurs in several chemical forms and oxidation states. The two states prevalent in water environment are arsenite $[\mathrm{As}(\mathrm{III})]$ and arsenate $[\mathrm{As}(\mathrm{V})]^{13}$. Arsenic(III) mostly exists in reducing ground waters and hydrothermal waters, whilst $\mathrm{As}(\mathrm{V})$ is more often present in surface waters and oxidizing ground waters ${ }^{14}$.

Arsenic is a geogenic water menace affecting millions of people all over the world and is regarded as the largest mass poisoning in history. Permanent arsenic intake can leads to chronic intoxication and prolonged arsenic exposure can damage the central nervous system, liver, skin and results in the appearance of diverse types of cancer, such as hyperkeratosis, lung and skin cancer and prostate cancers ${ }^{15-17}$

Arsenic in natural waters is a worldwide problem and its pollution has been reported recently in the USA, China, Chile, Bangladesh, Taiwan, Mexico, Argentina, Poland, Canada, Hungary, New Zealand, Japan and India ${ }^{10}$. The largest population at risk among the 21 countries with known groundwater arsenic contamination is in Bangladesh, followed by West Bengal in India ${ }^{18}$.

Due to high toxicity and carcinogenic effect of arsenic, World Health Organization, European Commission and the United States Environmental Protection Agency have recommended a maximum contaminant level of $10 \mu \mathrm{g} / \mathrm{L}$ for arsenic in drinking water ${ }^{19,20}$. In Iran, a maximum arsenic level of 10 $\mu \mathrm{g} \mathrm{L}^{-1}$ is permitted in drinking water by the Institute of Standard and Industrial Research of Iran.

The removal of arsenic from contaminated water is an important subject worldwide, which has recently attracted great attentions because drinking water is considered as the main source of exposure to inorganic arsenic ${ }^{21}$. During the recent years several treatment technologies have been applied for the removal of arsenic from water, including chemical oxidation ${ }^{22}$, dissolved air flotation process ${ }^{23}$, adsorption ${ }^{24-26}$, ion exchange ${ }^{27}$, membrane processes ${ }^{28-33}$, electrocoagulation ${ }^{34-36}$, chemical coagulation $^{37,38}$, nanotechnology $\mathrm{y}^{39,40}$, constructed wetlands ${ }^{41}$ 
and biological process ${ }^{42,43}$. Each method has its advantages and disadvantages and individual water treatment plant may choose the method that best suits their financial and managerial situations.

Coagulation and adsorption processes are most promising for removal of arsenic from high-arsenic water because of the low cost and high efficiency and are widely used in the developing world ${ }^{44,45}$. Previous studies on removal of arsenic have reported coagulation to be effective and economical compared with adsorption and ion exchange ${ }^{46,47}$. Commonly used chemicals in this technique are aluminum salts such as aluminum sulfate and ferric salts such as ferric chloride or ferric sulfate because of theirs low cost and relative ease of handling. In arsenic removal by this process, chemicals transform dissolved arsenic into an insoluble solid which is precipitated. Dissolved arsenic may also be adsorbed on the solid hydroxide surface site and be coprecipitated with other precipitating species ${ }^{48}$. The solids can be removed through sedimentation and/or filtration.

Natural coagulants of vegetable and mineral origin were in use in water treatment before the advent of chemical salts, but they have not been able to compete effectively because of the fact that a scientific understanding of their effectiveness and mechanism of action was lacking. Thus far, use of natural coagulants has been discouraged without any scientific evaluation. They have succumbed progressively under modernization and survived only in remote areas of some developing countries $^{49}$. However, there has been a resurgence of interest in natural coagulants for water treatment in developing countries, mainly due to the advantages such as biodegradability, low sludge production and fewer risks to health and environment ${ }^{50,51}$.

Usage of natural coagulants such as Moringa oleifera is better than chemical coagulant ${ }^{52,53}$. Moreover, sludge generated using Moringa oleifera as coagulant is less bulky compared to a chemical coagulant ${ }^{54}$. Ndabigengesere and Narasiah ${ }^{53}$ documented that the mechanism of coagulation with Moringa oleifera appeared to consist of adsorption and neutralization of the colloidal charges. Usage of Moringa oleifera as natural coagulant had also been reported by other researchers ${ }^{54,55}$.

Moringa peregrina is a desert species. Its occurrence in Iran is restricted to the southeast of the Sistan and Baluchestan province. Globally, it grows in Northeast Africa and Southwest Asia. The ground where Moringa peregrina grows is usually covered with coarse rock debris, which characterizes the upstream runnels at the mountain bases and slopes ${ }^{56}$.

The main objective of this research was to evaluate the feasibility of using the Moringa peregrina seed extract as a natural coagulant for the removal of arsenic from aqueous solutions. The effects of different parameters including solution $\mathrm{pH}$, coagulant dosage and initial arsenic concentration were also studied.

\section{EXPERIMENTAL}

Preparation of Moringa peregrina seed extract: Dry Moringa eregrina seeds were collected around the vicinity of Nikshahr city, Sistan and Baluchestan province, Iran. The preparation and extraction process was carried out in the following way: The seeds coats and wings were removed and seeds were reduced into powder by a domestic mill. A 1-M $\mathrm{NaCl}$ solution was prepared and $5 \mathrm{~g}$ of powder were put into $100 \mathrm{~mL}$ of it. The $\mathrm{NaCl}$ solution with powder was stirred for $0.5 \mathrm{~h}$ at room temperature (around $20{ }^{\circ} \mathrm{C}$ ) to extract the coagulation active components. No $\mathrm{pH}$ modification was needed, as natural $\mathrm{pH} 7$ was achieved. Then, the extract was filtered twice: once through commercial filter paper on Büchner funnel and once again through a fine filtering millipore system $(0.45 \mu \mathrm{m}$ glass fiber $)$. The result is a clear, milk-like liquid. Moringa peregrina stock solution prepared in this way was used the same day it was produced, although there are references that point the stability of the extract $t^{50}$.

Arsenic solution preparation: All the chemicals used were of analytical reagent grade. Stock solution of As(V) were prepared by dissolving sodium salt heptahydrate $\left(\mathrm{Na}_{2} \mathrm{HAsO}_{4} \cdot 7 \mathrm{H}_{2} \mathrm{O}\right)$ in double distilled water (at a concentration of $100 \mathrm{mg} \mathrm{L}^{-1}$ ) and the experimental solutions were obtained by diluting the stock solution to the required concentrations $\left(100,200,500 \mu \mathrm{g} \mathrm{L}^{-1}\right)$. The solution $\mathrm{pH}(2-11)$ was adjusted to desired values with $1 \mathrm{M} \mathrm{HCl}$ or $1 \mathrm{M} \mathrm{NaOH}$.

Coagulation experiments: Jar test is the most widely used method for evaluating and optimizing the coagulationflocculation processes. This study consists of batch experiments involving rapid mixing, slow mixing and sedimentation. The Phipps and Bird jar test apparatus was used in all the coagulation experiments. Glass beakers of $1 \mathrm{~L}$ filled with the model arsenic solution were used. The apparatus allowed six beakers to be agitated simultaneously and rotational speed could be varied between 0 and 100 rotations per minute (rpm), thus allowing simulation of different mixing intensities and resulting flocculation process.

In a typical run, beakers were filled with $1 \mathrm{~L}$ of the model arsenic solution, placed on the floc illuminator and agitated at the preselected intensity of rapid mixing. During rapid mixing, the coagulant dosage was added into each beaker using Eppendorf pipettes. The duration of rapid mixing was controlled with a stopwatch. After rapid mixing, the preselected intensity of slow mixing was quickly established and its duration was controlled again with the stopwatch. After slow mixing, the beakers were carefully removed from the floc illuminator and were placed in a safe place for the sedimentation phase to take place. In this study, the intensity and duration of both rapid mixing and slow mixing were fixed respectively at $100 \pm 2 \mathrm{rpm}$ for $2 \mathrm{~min}$ in the case of rapid mixing and $40 \pm 2 \mathrm{rpm}$ for $20 \mathrm{~min}$ in the case of slow mixing for flocculation. The duration of sedimentation was kept constant at $0.5 \mathrm{~h}$. At the end of the settling period, water samples were taken from the supernatants, immediately vacuum filtered using a $0.45 \mu \mathrm{m}$ pore size membrane filter and stored at $4{ }^{\circ} \mathrm{C}$ for further analysis. All experiments were run at room temperature $\left(20 \pm 1{ }^{\circ} \mathrm{C}\right)$ and no $\mathrm{pH}$ control was exercized. The ranges employed for these parameters are given in Table-1. Finally the efficiency of arsenic removal, $\%$ removal, was calculated as:

$\%$ Removal $=\left(\mathrm{C}_{\mathrm{i}}-\mathrm{C}_{\mathrm{f}}\right) / \mathrm{C}_{\mathrm{i}} \times 100$

where $\mathrm{C}_{\mathrm{i}}$ is the initial concentration $\left(\mu \mathrm{g} \mathrm{L}^{-1}\right)$ and $\mathrm{C}_{\mathrm{f}}$ is the final arsenic concentration $\left(\mu \mathrm{g} \mathrm{L}^{-1}\right)$. 
TABLE-1

RANGES OF EXPERIMENTAL PARAMETERS

\begin{tabular}{lllll}
\hline $\mathrm{pH}$ & $\begin{array}{l}\text { Coagulant } \\
\text { dosage } \\
\left(\mathrm{mL} \mathrm{L} \mathrm{L}^{-1}\right)\end{array}$ & $\begin{array}{l}\text { Arsenic } \\
\text { concentration, } \\
\left(\mu \mathrm{g} \mathrm{L}^{-1}\right)\end{array}$ & $\begin{array}{l}\text { Rapid mixing, } \\
\text { slow mixing and } \\
\text { sedimentation, }\end{array}$ & $\begin{array}{l}\text { Turbidity, } \\
\text { NTU }\end{array}$ \\
\hline $2-$ & $0.1,0.3$, & $100,200,500$ & 2 min $(100 \mathrm{rpm})$, & $10,20,30$, \\
11 & $\begin{array}{l}0.5,1,2,3, \\
4,5\end{array}$ & & $\begin{array}{l}20 \min (40 \mathrm{rpm}) \\
\text { and 30 min }\end{array}$ & $\begin{array}{l}40,50, \\
100,150\end{array}$ \\
\hline
\end{tabular}

Moreover, after determination of optimum conditions ( $\mathrm{pH}$ and coagulant dose of Moringa peregrina seed extract) for arsenate removal, the effect of initial turbidity on As(V) removal efficiency was investigated at an initial arsenate concentration of 100, 200 and $500 \mu \mathrm{g} \mathrm{L} \mathrm{L}^{-1}$. Synthetic turbid water for coagulation tests was prepared by adding stock kaolin suspension into distilled water. Stock kaolin suspension contained $10 \mathrm{~g}$ of kaolin in $1 \mathrm{~L}$ of distilled water. Finally a series of jar tests were performed using the one liter of tap water with 100, 200, 300, 400 and $500 \mu \mathrm{g} \mathrm{L}^{-1}$ of As(V) concentration. The characterization of the tap water used for these experiments is listed in Table- 2 .

TABLE-2

TYPICAL WATER QUALITY CHARACTERISTICS USED FOR THE SOME EXPERIMENTS

\begin{tabular}{lc}
\hline Parameter & Concentration \\
\hline $\mathrm{pH}$ & 7.82 \\
Conductivity, $\mu \mathrm{S} \mathrm{cm}$ & -1 \\
Turbidity, NTU & 627 \\
Iron, $\mathrm{mg} \mathrm{L}^{-1}$ & 0.4 \\
Manganese, $\mathrm{mg} \mathrm{L}^{-1}$ & 0.04 \\
Sulfate, $\mathrm{m} \mathrm{L}^{-1}$ & 0.011 \\
Chloride, $\mathrm{mg} \mathrm{L}^{-1}$ & 41 \\
Sodium, $\mathrm{mg} \mathrm{L}^{-1}$ & 53 \\
Nitrate, $\mathrm{m} \mathrm{L}^{-1}$ & 26 \\
\hline
\end{tabular}

Analysis: The residual arsenic concentration in the solutions was analyzed by silver diethyl dithiocarbamate method (SDDC) using UV-VIS spectrophotometer (PG, Instruments Ltd) at $530 \mathrm{~nm}$. The $\mathrm{pH}$ of solution was measured using a $\mathrm{pH}-$ meter (Denver Ultra basic-UB10). Turbidity was measured using a turbidimeter (WTW 355 IR) and it was expressed in nephelometric turbidity units (NTU). Each experiment was carried out in duplicate and the average results are presented herein.

\section{RESULTS AND DISCUSSION}

Effect of initial pH: The pH of the solution is one of the most critical parameters in the coagulation process and pollutants removal from aqueous solutions ${ }^{57,58}$. In order to determine the desired $\mathrm{pH}$ for removal of $\mathrm{As}(\mathrm{V})$ by Moringa peregrina seed extract as a natural coagulant, the uptake of $\mathrm{As}(\mathrm{V})$ as a function of hydrogen ion concentration was studied. Fig. 1 shows the effects of initial $\mathrm{pH}$ values within the range of 2-11 on the efficiency of As(V) removal by Moringa peregrina seed extract with initial dosage of $1 \mathrm{~mL} \mathrm{~L}^{-1}$. As it can be seen, maximum efficiency was obtained at initial $\mathrm{pH} 6$ for all initial concentrations of arsenate. On the other hand, the optimal arsenic removal can be achieved at pH 6 and then gradually declines as the $\mathrm{pH}$ is further increased and decreased. The highest removal was found to be 98.61, 99.032 and 98.976 $\%$ at initial $\mathrm{As}(\mathrm{V})$ concentration 100, 200 and $500 \mu \mathrm{g} \mathrm{\textrm {L } ^ { - 1 }}$ respectively, as a result of precipitation, co-precipitation and adsorption mechanisms.

The results showed that the extract of Moringa peregrina seed has a minimal effect on the $\mathrm{pH}$ of the samples. This result is in agreement with results obtained by Yarahmadi et al. ${ }^{59}$ on removal of turbidity by Moringa oleifera seed extract. Moreover they were reported that the efficiency of the Moringa oleifera extract as a coagulant is not affected by $\mathrm{pH}^{59}$.

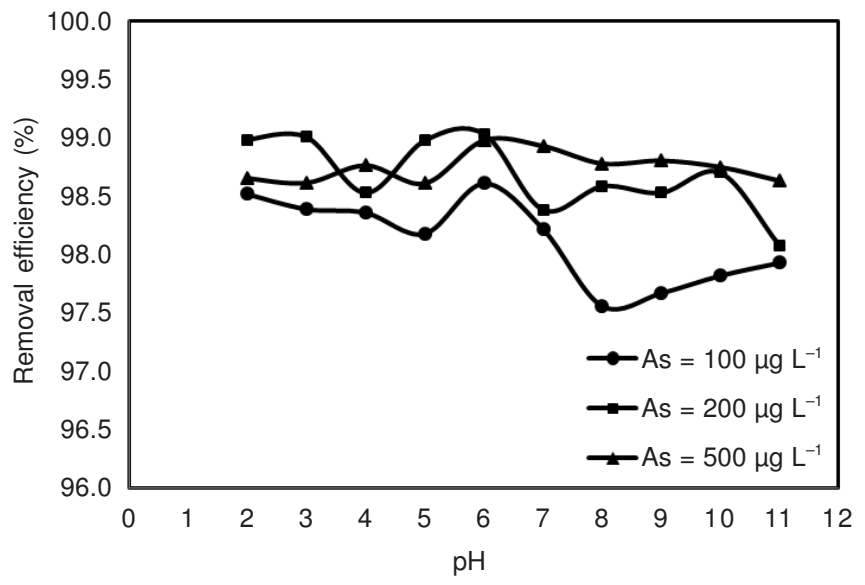

Fig. 1. Effect of $\mathrm{pH}$ on removal of $\mathrm{As}(\mathrm{V})$ (Moringa peregrina seed extract dose $=1 \mathrm{~mL} \mathrm{~L}^{-1}$ )

Effect of coagulant dose: Coagulation dosage is one of the most important parameters that have been considered to determine the optimum condition for the performance of coagulants in coagulation and flocculation. Essentially, insufficient dosage or overdosing would result in the poor performance in flocculation. Therefore, it is significant to determine the optimum dosage in order to minimize the dosing cost and sludge formation and also to obtain the optimum performance in treatment. Therefore, the effect of coagulant dose (Moringa peregrina seed extract) on $\mathrm{As}(\mathrm{V})$ uptake was depicted in Fig. 2, which showed that coagulation efficiency of As(V) changed with an increase in dosage of Moringa peregrina seed extract from 0.1 to $5 \mathrm{~mL} \mathrm{~L}^{-1}$. The optimum dosage of Moringa peregrina seed extract for both low and high arsenic solutions was 1 and $0.5 \mathrm{~mL} \mathrm{~L}^{-1}$. On the other hand, the highest removal was found to be $98.45,99.104$ and $99.8 \%$ at initial As(V) concentration 100, 200 and $500 \mu \mathrm{g} \mathrm{L}^{-1}$ at coagulant dosage 1.1 and $0.5 \mathrm{~mL}$ per $1 \mathrm{~L}$, respectively. More increase the dosage of coagulant did not help in improving the removal of arsenic; in fact this increased the residual arsenic of the coagulated sample. Obtained results at optimum $\mathrm{pH}$ values of coagulant are in good agreement with the values given in literatures ${ }^{60,61}$. On the other hand a further increase in coagulant dose causes restabilization of the particles as the charge reversal on the colloids occurs ${ }^{62}$. Generally, it can be concluded that lower doses of investigated natural coagulants were better than higher ones. This is very important not only for process economy but also for lower organic matter load in processed water because it is known that high organic load might cause microbial growth $^{63}$. Nevertheless, obtained results are valid only in applied conditions.

However, higher removal ( $>99 \%$ ) was achieved for the samples with high concentration of arsenic $\left(500 \mu \mathrm{g} \mathrm{L}^{-1}\right)$. This 
was in agreement with findings reported by other researchers $^{55,64}$. They documented that the increase in turbidity removal with increasing the initial turbidity of a sample. Also, as it can be seen, after the coagulation and flocculation experiments using Moringa peregrina seed extract, residual arsenate concentrations decreased to below $10 \mu \mathrm{g} \mathrm{L}^{-1}$ which is the maximum contaminant level of arsenic in drinking water determined by the USEPA and WHO.

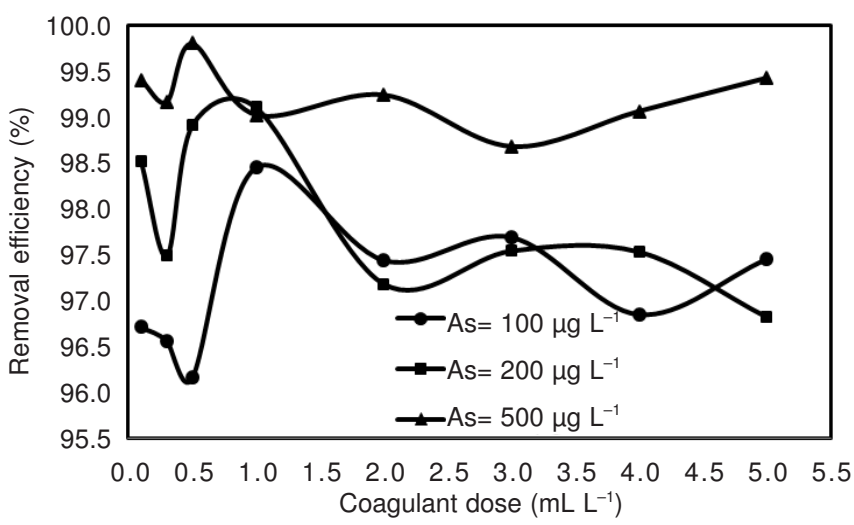

Fig. 2. Effect of coagulant dose (Moringa peregrina seed extract) on removal of $\mathrm{As}(\mathrm{V})$, (at optimum $\mathrm{pH}=6$ )

Effect of turbidity on removal of $\operatorname{arsenic}(\mathrm{V})$ : The study of the effect of initial turbidity on the arsenate removal at various initial concentration of $\mathrm{As}(\mathrm{V})$ (Figs. 3-5) indicates that turbidity addition can enhance slightly the arsenate removal more than when the coagulant is used alone. Nevertheless, further addition of turbidity decreased removal efficiencies of $\mathrm{As}(\mathrm{V})$. The best efficiency was obtained in initial turbidity 50 NTU and pH 6 for all the experiments.

Experiments on tap water: Some experiments was performed to study the performance of Moringa peregrina seed extract as coagulant for arsenate removal from natural (tap) water samples with different initial $\mathrm{As}(\mathrm{V})$ concentrations of 100, 200, 300, 400 and $500 \mu \mathrm{g} \mathrm{L} \mathrm{L}^{-1}$. The results obtained from jar test experiments with $1 \mathrm{~mL} \mathrm{~L}^{-1}$ Moringa peregrina seed extract are shown in Fig. 6. As it can be seen, the removal efficiency of $\mathrm{As}(\mathrm{V})$ increased with its increase in initial concentration up to $400 \mu \mathrm{g} \mathrm{L}^{-1}$ and then decreased, so maximum efficiency was obtained at initial concentration $400 \mu \mathrm{g} \mathrm{L}^{-1}$.

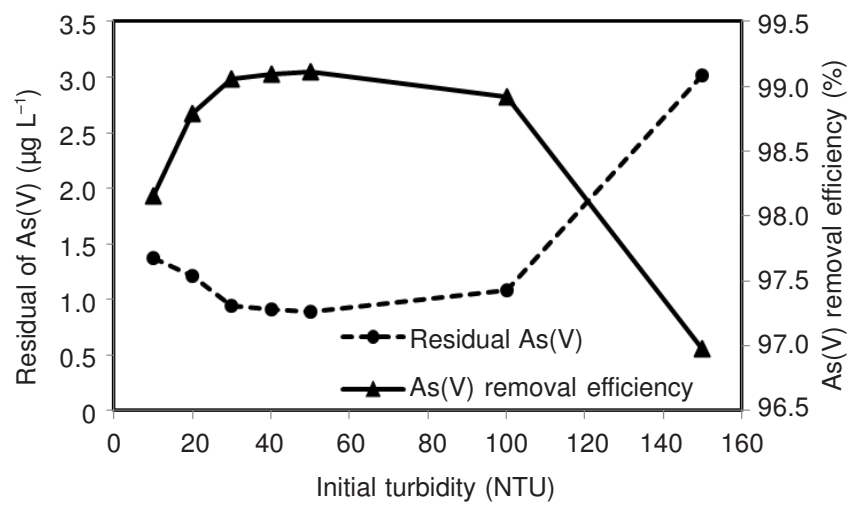

Fig. 3. Effect of initial turbidity on $\mathrm{As}(\mathrm{V})$ removal from synthetic solution (Initial concentration of $\mathrm{As}(\mathrm{V})=100 \mu \mathrm{g} \mathrm{L} \mathrm{L}^{-1}, \mathrm{pH}=6$, coagulant dose $=1 \mathrm{~mL} \mathrm{~L}^{-1}$ )

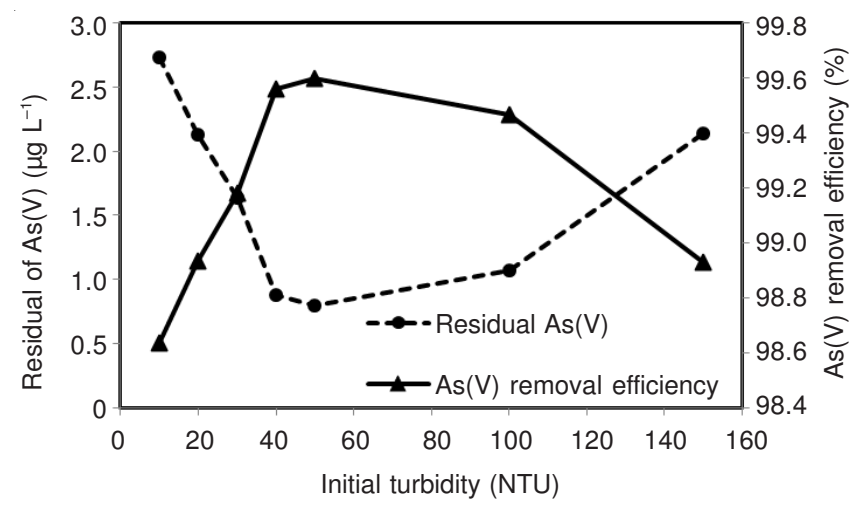

Fig. 4. Effect of initial turbidity on $\mathrm{As}(\mathrm{V})$ removal from synthetic solution (Initial concentration of $\mathrm{As}(\mathrm{V})=200 \mu \mathrm{g} \mathrm{L} \mathrm{L}^{-1}, \mathrm{pH}=6$, coagulant dose $\left.=1 \mathrm{~mL} \mathrm{~L}^{-1}\right)$

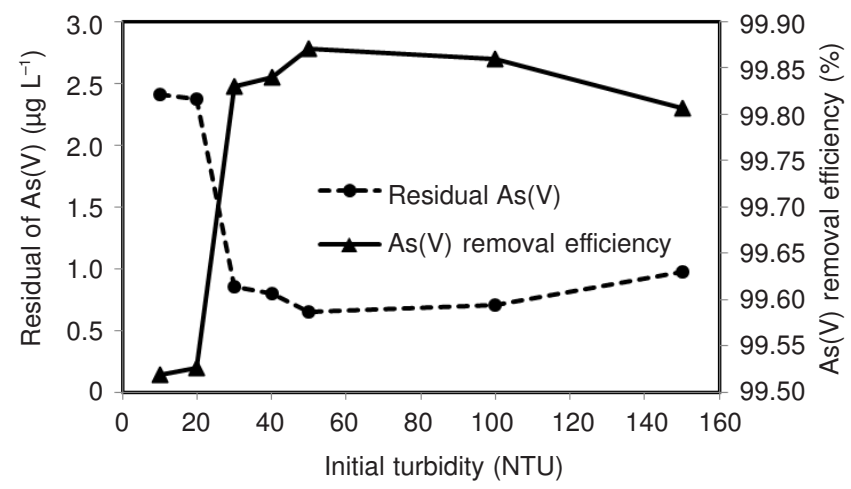

Fig. 5. Effect of initial turbidity on $\mathrm{As}(\mathrm{V})$ removal from synthetic solution (Initial concentration of $\mathrm{As}(\mathrm{V})=500 \mu \mathrm{g} \mathrm{L}^{-1}, \mathrm{pH}=6$, coagulant dose $=1 \mathrm{~mL} \mathrm{~L}^{-1}$ )

As can be seen from Fig. 6, after the coagulation and flocculation experiments using Moringa peregrina seed extract, residual arsenate concentrations decreased to below

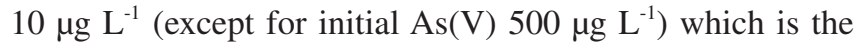
maximum contaminant level of arsenic in drinking water determined by the USEPA and WHO. It can be concluded that for higher concentration of $\mathrm{As}(\mathrm{V})$, more coagulant required to reach the current standards.

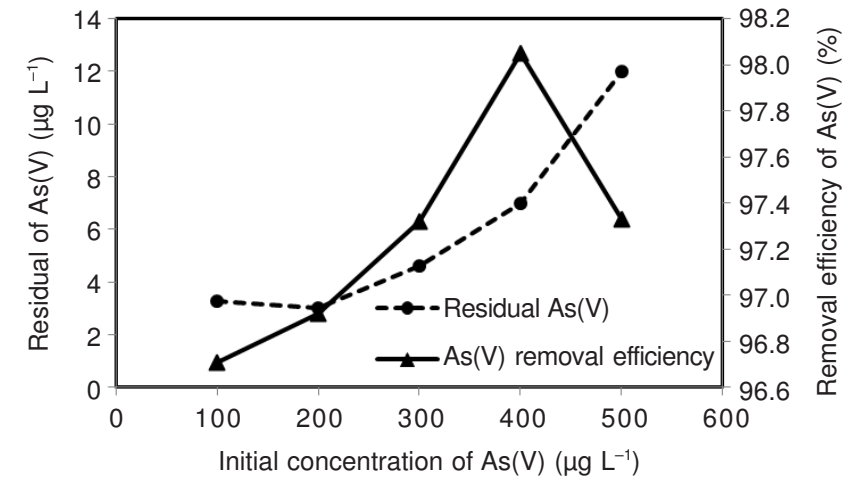

Fig. 6. Removal efficiency of $\mathrm{As}(\mathrm{V})$ from tap water at different initial concentration of $\mathrm{As}(\mathrm{V})$ (Coagulant dose $=1 \mathrm{~mL} \mathrm{~L}^{-1}$ )

\section{Conclusion}

The coagulation/flocculation method by Moringa peregrina seed extract as a natural coagulant was used for 
arsenic $[\mathrm{As}(\mathrm{V})]$ removal from aqueous solutions. The experimental studies demonstrated that the Moringa peregrina seed extract is an effective and reliable coagulant considering the required concentration and residual $\mathrm{As}(\mathrm{V})$ after sedimentation in the effluent. The optimum $\mathrm{pH}$ range for arsenic removal by coagulation using Moringa peregrina seed extract was 6. At the constant $\mathrm{pH}$ of 6 , the percentage of $\mathrm{As}(\mathrm{V})$ removal increased with addition of coagulant due to chemical destabilization of colloidal particles by neutralizing the charges that keeps them apart. It was found that the arsenate concentration can be reduced down to less than $10 \mu \mathrm{g} \mathrm{L}^{-1}$ in the initial arsenate concentration ranging from 100 to $500 \mu \mathrm{g} \mathrm{L}^{-1}$, which is the maximum contaminant level of arsenic in drinking water determined by the USEPA and WHO. Finally it can be concluded that Moringa peregrina seed extract is an efficient coagulant for arsenate removal in various concentrations from water and wastewater.

\section{ACKNOWLEDGEMENTS}

The authors express their appreciation to Department of Environmental Health Engineering and Health School of Zahedan University of Medical Sciences for the financial support of this study (Project Number: 91-2506).

\section{REFERENCES}

1. A. Maleki, A.H. Mahvi, M.A. Zazouli, H. Izanloo and A.H. Barati, Asian. J. Chem., 23, 1373 (2011).

2. J. Nouri, A.H. Mahvi and E. Bazrafshan, Int. J. Environ. Res., 4, 201 (2010).

3. L. Rafati, A.H. Mahvi, A.R. Asgari and S.S. Hosseini, Int. J. Environ. Sci. Technol., 7, 147 (2010).

4. E. Bazrafshan, A.H. Mahvi and M.A. Zazouli, Asian. J. Chem., 23, 5506 (2011).

5. Z. Atafar, A. Mesdaghinia, J. Nouri, M. Homaee, M. Yunesian, M. Ahmadimoghaddam and A.H. Mahvi, Environ. Monit. Assess., 160, 83 (2010).

6. A.H. Mahvi, F. Gholami and S. Nazmara, Eur. J. Scient. Res., 23, 197 (2008).

7. E. Bazrafshan, A.H. Mahvi, S. Naseri and A.R. Mesdaghinia, Turk. J. Eng. Environ. Sci., 32, 59 (2008).

8. A.H. Mahvi, R. Nabizadeh, F. Gholami and A. Khairi, Iran J. Environ. Health., 4, 191 (2007).

9. M. Heidari, F. Moattar, S. Naseri, M.T. Samadi and N. Khorasani, Int. J. Environ. Res., 5, 447 (2011).

10. M.A. Khan and Y.-S. Ho, Asian J. Chem., 23, 1889 (2011).

11. M.B. Baskan and A. Pala, Desalination, 254, 42 (2010).

12. L. Dong, P.V. Zinin, J.P. Cowen and L.C. Ming, J. Hazard. Mater, 168, 626 (2009).

13. A. Figoli, A. Cassano, A. Criscuoli, M.S.I. Mozumder, M.T. Uddin, M.A. Islam and E. Drioli, Water. Res., 44, 97 (2010).

14. K.R. Henken and A. Hutchison, in ed.: K.R. Henken, Arsenic Chemistry. Arsenic Environmental Chemistry, Health Threats and Waste Treatment. John Wiley \& Sons Ltd., Chichester (2009).

15. Y. Li, J. Wang, Z. Luan and Z. Liang, J. Hazard. Mater., 177, 131 (2010).

16. Y. Jeong, M. Fan, S. Singh, C.L. Chuang, B. Saha and J.H. Leeuwen, Chem. Eng. Process., 46, 1030 (2007).

17. P.F. Hudak, Int. J. Environ. Res., 4, 229 (2010).

18. D. Mohan and Jr. Ch. U. Pittman, J. Hazard. Mater, 142, 1 (2007).

19. N. Haque, G. Morrison, I.C. Aguilera and J.L.G. Torresdey, Microchem. J., 88, 7 (2008).

20. World Health Organization, Guidelines for Drinking Water Quality Incorporating First and Second Addenda, Recommendations, WHO, Geneva, Switzerland, edn. 3, vol. 1 (2008).

21. I. Villaescusa and J.C. Bollinger, Rev. Environ. Sci. Biotechnol., 7, 307 (2008).
22. M. Borho and P. Wilderer, Water. Sci. Technol., 34, 25 (1996).

23. F.K. Mostafapour, H. Pourmoghadas, M.R. Shahmansouri and A. Parvaresh, J. Appl. Sci., 6, 1153 (2006).

24. H. Takanashi, A. Tanaka, T. Nakajima and A. Ohki, Water. Sci. Technol., 50, 23 (2004).

25. M.N. Amin, T. Kaneco, A. Kitagawa, H. Begum, T. Katsumata and K. Suzuki, Ind. Eng. Chem. Res., 45, 8105 (2006).

26. M. Salim and Y. Munekage, Int. J. Environ. Res., 3, 13 (2009).

27. J. Kim and M.M. Benjamin, Water. Res., 38, 2053 (2004).

28. T. Geucke, S.A. Deowan, J. Hoinkis and Ch. Pätzold, Desalination, 239, 198 (2009).

29. R.Y. Ning, Desalination, 143, 237 (2002).

30. S. Velixarov, J.G. Crespo and M.A. Reis, Rev. Environ. Sci. Biotechnol., 3, 361 (2004).

31. D.H. Kim, K.W. Kim and J. Cho, Water Health, 4, 215 (2006).

32. M.M. Gholami, M.A. Mokhtari, A. Aameri and M.R. Alizadeh Fard, Desalination, 200, 725 (2006).

33. H. Saitua, R. Gil and A.P. Padilla, Desalination, 274, 1 (2011).

34. P.R. Kumar, S. Chaudhari, K.C. Khilar and S.P. Mahajan, Chemosphere, 55, 1245 (2004).

35. J.R. Parga, D.L. Cocke, J.L. Valenzuela, J.A. Gomes, M. Kesmez, G. Irwin, H. Moreno and M. Weir, J. Hazard. Mater, 124, 247 (2005).

36. E. Lacasa, P. Canizares, C. Sáez, F.J. Fernández and M.A. Rodrigo, Sep. Purif. Technol., 79, 15 (2011).

37. S.R. Wickramasinghe, B. Han, J. Zimbron, Z. Shen and M.N. Karim, Desalination, 169, 231 (2004).

38. B. Ghosh, M.C. Das, A.K. Gangopadhyay, T.B. Das, K. Singh, S. Lal, S. Mitra, S.H. Ansari, T.K. Goswami, S.K. Chakraborty and N.N. Banerjee, Indian J. Chem. Technol., 10, 87 (2003).

39. H. Zhu, Y. Jia, X. Wu and H. Wang, J. Hazard. Mater, 172, 1591 (2009).

40. M.R. Boldaji, R. Nabizadeh, M.H. Dehghani, K. Nadafi and A.H. Mahvi, J. Environ. Sci. Health. Part A, 45, 946 (2010).

41. A.K. Lizama, T.D. Fletcher and G. Sun, Chemosphere, 84, 1032 (2011).

42. I. Katsoyiannis, A. Zouboulis, H. Althoff and H. Bartel, Chemosphere, 47, 325 (2002).

43. I.A. Katsoyiannis and A.I. Zouboulis, Water. Res., 38, 17 (2004).

44. S. Song, A. Lopez-Valdivieso, D.J. Hernandez-Campos, C. Peng, M.G. Monroy-Fernandez and I. Razo-Soto, Water. Res., 40, 364 (2006).

45. S.Y. Choong, T.G. Chuah, Y. Robiah, F.L.G. Koay and I. Azni, Desalination, 217, 139 (2007).

46. D. Lakshmanan, D.A. Clifford and G. Samanta, Water. Res., 44, 5641 (2010).

47. G. Ghurye, D.A. Clifford and A.R. Tripp, J. AWWA, 96, 143 (2004).

48. P. Mondal, C.B. Majumder and B. Mohanty, J. Hazard. Mater., B137, 464 (2006).

49. A. Ndabigengesere and K.S. Narasiah, Water. Res., 32, 781 (1998).

50. S. Katayon, M.M. Noor, M. Asma, L.A. Abdul Ghani, A.M. Thamer, I. Azni, J. Ahmad, B.C. Khor and A.M. Suleyman, Bioresour. Technol., 97, 1455 (2006).

51. T. Shahriari, G.N. Bidhendi and Sh. Shahriari, Int. J. Environ. Res., 6, 259 (2012).

52. A. Ndabigengesere, K.S. Narasiah and B.G. Talbot, Water Res., 29, 703 (1995)

53. A. Ndabigengesere and K.S. Narasiah, Environ. Technol., 17, 1103 (1997).

54. G.L. McConnachie, G.K. Folkard, M.A. Mtawali and J.P. Sutherland, Water. Res., 33, 1425 (1999).

55. A.M. Suleyman and C.A. Okuofu, Int. J. Environ. Stud., 48, 263 (1995).

56. A.K. Hegazy, O. Hammouda, J. Lovett-Doust and N.H. Gomaa, J. Arid Environ., 72, 1537 (2008).

57. B. Shi, G. Li, D. Wang, C. Feng and H. Tang, J. Hazard. Mater., 143, 567 (2007).

58. W. Hu, Water Res., 35, 3147 (2001).

59. M. Yarahmadi, M. Hossieni, B. Bina, M.H. Mahmoudian, A. Naimabadie and A. Shahsavani, World Appl. Sci. J., 7, 962 (2009).

60. M. Donmez and F. Akbal, World Acad. Sci., Eng. Technol., 78, 437 (2011).

61. R. Sanghi, B. Bhattacharya, A. Dixit and V. Singh, J. Environ. Manage., 81, 36 (2006)

62. J. Duan and J. Gregory, Adv. Colloid. Interf. Sci., 100-102, 475 (2003).

63. M. Šciban, M. Klašnja, M. Antov and B. Škrbic, Bioresour. Technol., 100, 6639 (2009).

64. J. Zhang, F. Zhang, Y. Luo and H. Yang, Process. Biochem., 41, 730 (2006). 